\title{
Teacher Attitude for Better Education: The Relationship between Affection, Support and Religiosity the Success of Inclusive Education
}

\author{
Amka Amka \\ Special Education Study Program, Faculty of Teacher Training and Education, \\ University of Lambung Mangkurat, Banjarmasin, 70125, Indonesia \\ Corresponding author : amka.plb@ulm.ac.id
}

\begin{abstract}
The teacher's positive attitude towards people with disabilities plays an important role in encouraging the success of inclusive education. Using a three-dimensional theory of attitude formation namely cognitive, affective, and conative, this study aims to measure the attitudes of teachers in South Kalimantan, Indonesia towards inclusive education $(\mathrm{N}=212)$ by proposing several variables that influence that attitude. Using one-way Manova, this study finds that female teacher shows better affective dimensions and students majoring in special education show greater support for inclusive education. In general, there are significant differences in attitudes between special and general teacher categories. Also, teachers with personal contact or experience with persons with disabilities exhibit better attitudes. There is no significant difference between experienced and inexperienced teachers. Religion also has an influence, religious teachers are better in the conative dimension, and less-religious teachers are better in cognitive dimensions.
\end{abstract}

Key words: Attitude, Teacher, Education, Inclusive, Indonesia

\section{INTRODUCTION}

Teachers are seen as a key factor in implementing inclusive education since teachers' positive attitudes play an important role in driving the success of education change in schools to be inclusive. The purpose of this study is to examine the attitudes of teachers in the South Kalimantan Province, Indonesia, towards inclusive education, and what variables influence their attitudes. Inclusive education in Indonesia is regulated in Law No. 8 of 2016 concerning Persons with Disabilities supersedes Law No 4 of 1997 deemed charity based and have no human rights perspective. In the old regulation, the fulfillment of the rights of persons with disabilities was still considered a social problem. Persons with disabilities have not had the opportunity to develop themselves through independence as dignified humans.

With the ratification of the Convention on the Rights of Persons with Disabilities on November 10, 2011, the Indonesian government wants to show commitment and sincerity to respect, protect and fulfill the rights of people with disabilities. The Indonesian law states that "persons with disabilities receive a quality education at education units in all types, lines, and levels of education in an inclusive and specific way" (Article 10). Also, persons with disabilities are entitled to adequate accommodations as students.

In Indonesia, the term 'inclusive education' began to get attention in 2001 when the government commences a pilot project on inclusive education (Nasichin, 2001). Indonesia officially recognized inclusive education when parliament passed a National Education System Law in 2003, which stipulates that all citizens with all types of disabilities are obliged to

ISSN 1869-0459 (print)/ ISSN 1869-2885 (online) 
participate in inclusive education. In the same year, the government also issued a decision on Inclusive Education for children with cognitive and physical disabilities. This regulation stipulates that inclusive education is education that guarantees equal access for students with all types of disabilities to obtain an education in public schools together with students who are not disabled (Sunardi, 2010, p.28).

In the present law, the local governments are obliged to facilitate the formation of Disability Service Units to support the implementation of inclusive and primary education. The unit's functions to include: increasing the educators' competence and education personnel in regular schools in dealing with students with disabilities; assist students with disabilities to support the smooth learning process; provide learning media and tools that are needed; provide consulting services and; develop cooperation with other institutions to improve the education quality for students with disabilities (Article 42).

This study aims to determine and then analyze how teachers' attitude in South Kalimantan Province towards inclusive education. With a population of 3.62 million. The province has an area that includes 2 cities and 11 districts. The local government noted that there are around two thousand more disabled children in this area (Effendi, 2018). The reason for choosing the area for this study is because it was established by the central government in 2012 as a pioneer in implementing provincial-level inclusive education. The central government sees great commitment and attention from the South Kalimantan provincial government to inclusive education.

\section{Previous research}

Research findings regarding teacher attitudes toward inclusive education sometimes present a confusing picture. Teachers seem to support inclusive education in general but tend not to like to be involved when it comes to inclusive teaching in their classrooms (de Boer et al., 2011). Also, their opinions on inclusive education tend to be based on the type of student disability. Therefore, the question is how positive the attitude of regular school teachers towards inclusive education for students with special needs. Hence, this study is conducted to investigate: (1) teacher attitudes towards inclusive education, and; (2) variables related to this attitude.

Supriyanto (2019) conducted a review of 27 pieces of literature involving 5,471 teachers which showed that most teachers had a positive attitude towards inclusive education. He said several studies also reported negative attitudes and neutrality. Although the term attitude is defined differently in several studies, he found that the education background and level, the training received, and the type of disability affected attitudes.

A study by Saloviita (2020) in Finland found that about $20 \%$ of teachers in the country reject inclusive education, and only $8 \%$ support it. According to her, attitudes towards inclusive education only have a strong relationship with the teacher category variable. Another study by Al-Zyoudi (2006) in Jordan found that teacher attitudes were greatly influenced by the nature and severity of the students' conditions with disabilities, the length of teaching experience, and the training received.

In an attitude study of 152 general education teachers towards inclusive education in the United Arab Emirates, Alghazo and Gaad (2004) found a significant difference in teacher 
attitudes influenced by teaching experience and student disabilities types. Teachers who have longer teaching experiences tend to show less resistance in integrating students with disabilities into their regular classrooms. In contrast, female teachers in the UAE, in general, prefer the separation of rooms between students with and without disabilities than their male counterparts. However, when asked about the extent of their acceptance with the type of disabled students, participants of both sexes showed more objections to severe disabilities, such as emotional disturbances and mental retardation. The order of preference reported, starting from the mildest, is a physical disability, learning disabilities, visual impairment, hearing loss, behavior difficulties, and mental retardation (Alghazo \& Gaad, 2004).

Buell et al. (1999) used a multivariate variance analysis to examine the differences in responses between 202 general teachers and 87 special education teachers in the United States to measure their belief in inclusive classes. Findings revealed that the general teacher group expressed a greater need for training to work with students with disabilities than special education teachers.

In a study of 1,623 pre-service teachers in Bangladesh, Ahsan et al. (2013) found that types of teacher education preparation programs were strong predictors of teacher self-efficacy to adopt inclusive education. Pre-service teachers who enroll in the special education track are more comfortable teaching students with disabilities than their peers who enroll in the general education track (Huang \& Chen, 2017).

A study by Pearson et al. (2003) in Hong Kong found that teachers sometimes had doubts about accepting students with special needs into regular classes. A reason that is often cited is that disabled students demand more time from teachers, consequently, less time is left for regular students. When the momentum arises to encourage and hold schools accountable for students' academic achievement, many teachers voice concerns. They feel unfair to be evaluated because they have to devote more time to helping students with disabilities and in the process, inadvertently, ignore other students (Pearson et al., 2003).

Using multiple regression models, Ahsan et al. (2013) confirm that age and previous experience with a disabled person is a strong predictor of teachers' willingness in Bangladesh to implement inclusive education. In addition, older teachers are less worried about teaching students with special needs. Previous experience seems to be an important variable. Those who have significant interactions, or personal contact, with people with disabilities, have fewer concerns than those who did not have prior interactions. In addition, the impact of professional development on teacher attitudes is very encouraging. In an experimental study in Greece conducted by Avramidis and Kalyva (2007), they randomly divided 155 general education teachers into a control group and an experimental group. The results showed that teachers who were actively involved in learning how to teach students with disabilities had far more positive attitudes towards inclusive education than their peers without such training.

Using the interview method, Scott et al. (2007) examined the views of 43 music teachers about inclusive education. They concluded that a positive attitude towards students with disabilities can be estimated based on perceptions of teacher professional competence and access to support and resources. Several studies show that teachers generally have a positive attitude towards the general philosophy of inclusive education (Abbott, 2006; Avramidis et al., 2000; Avramidis \& Norwich, 2002; Marshall et al., 2002), while other studies reveal that 
teachers have serious doubts towards the practice of inclusive education (Florian, 2008; Pearman et al., 1997; Ring \& Travers, 2005).

\section{Definition of 'attitude' in the context of inclusive education}

To be able to examine teachers' attitudes towards inclusive education, so the term 'attitude' must first be defined. Fishbein \& Ajzen (1975) provide one of the most well-known attitudes definitions. According to them, the attitude is, "a learned predisposition to respond in a manner that is consistently favorable or unfavorable manner with respect to a given object" (p. 6). According to Gall et al. (2003): "an attitude is an individual's point of view or disposition towards a particular object (person, object, and idea, etc.)" (p, 273). In this case, the attitude has three dimensions: cognitive, affective and behavior (Eagly \& Chaiken, 1993; Triandis, 1971).

According to Schiffman \& Kanuk (2004), the cognitive dimension of attitude is formed from experience and related information from various sources. Thus, the cognitive component consists of individual beliefs or knowledge of attitude objects. Teachers' beliefs or knowledge about educating children with special needs in an inclusive environment can represent this component, e.g. 'I believe that students with special needs are part of a public school.'

The affective dimension refers to feelings towards attitude objects (Schiffman and Kanuk, 2004). According to Eagly and Chaiken (1993), affective factors are based on emotional experiences or preferences, both positive (eg, excitement) and negative (ie, anger) arising from experiences with attitude objects (Derbaix \& Pham, 1991). Positive and negative influences contribute to the assessment of satisfaction or dissatisfaction with the attitude objects (Horley \& Little, 1985). Concerning inclusive education, the affective component reflects the teacher's feelings in educating students with special needs, such as the statement that reflect negative emotion 'I am afraid students with behavioral problems can disrupt classroom order.'

The behavioral dimension reflects a person's tendency to act on attitude objects in a certain way. Behavioral factors (conative) are related to one's open actions concerning the attitude object (MacKenzie \& Lutz, 1989; Eagly \& Chaiken 1993). Conative discusses the possibility that someone will exhibit certain behaviors on the object of attitude (Schiffman \& Kanuk, 2004). According to Havitz \& Dimanche (1997) and McIntyre (1992), involvement is seen as a core concept in explaining individual participation in their activities and actions to attitude object. In inclusive education, this includes the teacher's views on how to act, either positively or negatively, with children with special needs in the classroom, e.g. 'I will refuse to provide additional support to students with special needs.'

This study aims to examine attitude of teachers and also prospective teachers, who are generally teacher education students, towards inclusive education based on various factors of individual background such as gender, majoring in education (general and special), teacher categories (general and special), personal contact with the disabled, as well as teaching and religious experience.

This study applies the three dimensions of attitude formation theory, namely cognitive, affective, and conative (behavior). Although there is a view that the combined scores of the three dimensions are considered to be more predictive and responsive to attitude objects than

ISSN 1869-0459 (print)/ ISSN 1869-2885 (online) 
relying solely on cognitive, affective, or conative aspects separately (Eagly and Chaiken 1993; Fishbein and Ajzen 1975), but in this study, attitude measurement is not measured by combining scores but by separate measurement. The rational reason for this is that good knowledge of an object (cognitive dimension) does not have to be in line with a feeling of affection towards the attitude object because they may be the opposite. Thus the research questions can be formulated as follows: (1) Does gender, education majors, teacher categories, personal contacts, teaching experience, and religiosity influence the attitude in the cognitive dimension ?; (2) Does gender, education majors, teacher category, personal contact, teaching experience, and religiosity influence attitude in the affective dimension ?; (3) Does gender, education majors, teacher category, personal contact, teaching experience, and religiosity influence attitude in conative dimension?

Based on previous studies and research questions as outlined above, this study would like to submit the hypothesis as follows:

H1: There are differences between male and female teachers, teachers with special and general educational backgrounds, experienced and less-experienced, general and special teachers, teachers with personal contacts and without personal contacts on attitudes in the cognitive dimension.

H2: There are differences between male and female teachers, teachers with special and general educational backgrounds, experienced and less-experienced, general and special teachers, teachers with personal contacts and without personal contacts on attitudes in the affective dimension.

H3: There are differences between male and female teachers, teachers with special and general educational backgrounds, experienced and less-experienced, general and special teachers, teachers with personal contacts and without personal contacts on attitudes in the conative dimension.

\section{The Role of Religion}

Religion and culture adopted by the people of a country are often becoming the driving force for teachers' positive attitudes towards students with disabilities. Naemiratch \& Manderson (2009) who studied people's understanding of disability in northeastern Thailand found that usually, a person expresses kindness towards someone who is suffering by treating them with compassion. When people show their generosity and help those who suffer, there is a belief that they are building good karma to avoid misfortune in their later lives. This shows that Buddhism provides a philosophical basis for the application of inclusive education.

Buddhists believe in Karma that if someone is born in defect, either physically or mentally, then it comes from that person's bad deeds in his past life (Kantavong, 2018). People must accept their distress or suffering, and others can express their kindness by helping or letting that person pay for their karma (Kantavong, 2018). Vorapanya \& Dunlap (2014) noted that the problem of special education must be seen through a cultural perspective, especially in terms of religion and family structure. Their study of 10 inclusive schools in Thailand found that 7 out of 10 schools did so with love as the core of their professional practice. They report an interesting observation from their research, parents of regular students are ready to accept the 
disabilities of other people's children, but their main concern is whether their children are at risk of learning with students with disabilities (Vorapanya \& Dunlap, 2014).

In Indonesia, the Islamic religion adopted by the majority of Indonesian people has a role in encouraging the emergence of positive attitudes of Muslim teachers towards students with disabilities and support for inclusive education (Wathoni, 2013; Subekti, 2017). The holy book of Islam Al-Qur'an teaches that humans were created differently to be in touch with one another (inclusive) and that the glory of mankind in the sight of Allah is his devotion. Also, Allah does not see the (physical) form of a Muslim, but Allah sees his heart and deeds (Hifni, 2018). In a story told that God once rebuked the Prophet Muhammad SAW because he was surly and turned away from the blind (Gaddafi, 2017).

Inclusive education and Islamic teachings have the same philosophical (Wathoni, 2013; Subekti. 2017). In an Islamic perspective education is a prerequisite to be able to understand other Islamic obligations as well as to build culture/civilization, while in an inclusive perspective education is a human right. The statement of education as a right or obligation is not something to be debated because the difference lies only in the point of view of the same substance: 'education as a right' is more anthropocentric and 'education as an obligation' is more theocentric. (Wathoni, 2013; Subekti. 2017). By viewing education as an obligation, every Muslim must not be marginalized and excluded from obtaining educational services to develop the human personality by recognizing all the power and potential that students possess.

\section{Religiosity Scale}

Understanding of religion and religiosity as variables that have several dimensions is rooted in religious theories that emerged since the early 1900s and have been repeatedly revised, especially during the second half of the 1900s (Pearce et al., 2016). For example, Joachim Wach (1944, in Hart, 1945) proposes a three-dimensional model including a "theoretical" dimension, which refers to the power of doctrinal obedience, the "cult" dimension which is the level of one's worship and worship practices, and the "sociological" dimension, or social involvement in fellowship activities.

Huber \& Huber (2012) developed The Centrality of Religiosity Scale (CRS) to measure religiosity. CRS is a measure of centrality namely an important measure of religious meaning in an individual's life. CRS measures the general intensity of five dimensions of religiosity: intellectual, ideology, public practice, private practice, and religious experience. These five dimensions can jointly be considered as representative for the whole of religious life and are measured by a Likert scale that allows respondents to express how much they agree or disagree with a particular statement of religiosity.

Diduca \& Joseph (1997) developed the Dimension of Religiosity Scale (DR Scale) which has 24 statement items to assess the four dimensions of religious thought and behavior namely: (1) preoccupation (for example, I often think of God), (2) guidance (for example, I pray to be guided in daily life), (3) beliefs (for example, I believe that Christ exists) and (4) emotional involvement (for example, I feel happy when I think about God).

Glock (1962) distinguishes five relatively independent dimensions of religiosity and he claims that the five dimensions include all forms of religious expression that may be found in all world religions. The five dimensions are the ideological dimension or dimensions of the 
belief that contain agreement with the basic beliefs of religion, for example, belief in God. The ritualistic dimension is divided into ritual and devotion sub-dimensions. The assumption is that very formal rituals performed together (public) do not always mean the same as acts of private, informal and spontaneous worship. Furthermore, he distinguishes between the dimensions of experience, the dimension of knowledge, and the dimension of secular consequences. The researchers sought to perfect the conceptualization of prior religiosity through various empirical investigations to produce various dimensional models for different religious groups. The study of religiosity as explained above raises the question: Does religiosity affect the attitudes of teachers towards inclusive education ?. Based on this question, the following hypothesis is proposed,

H4: Religiosity influences teachers' attitude differences toward inclusive education in the cognitive, affective and conative dimensions.

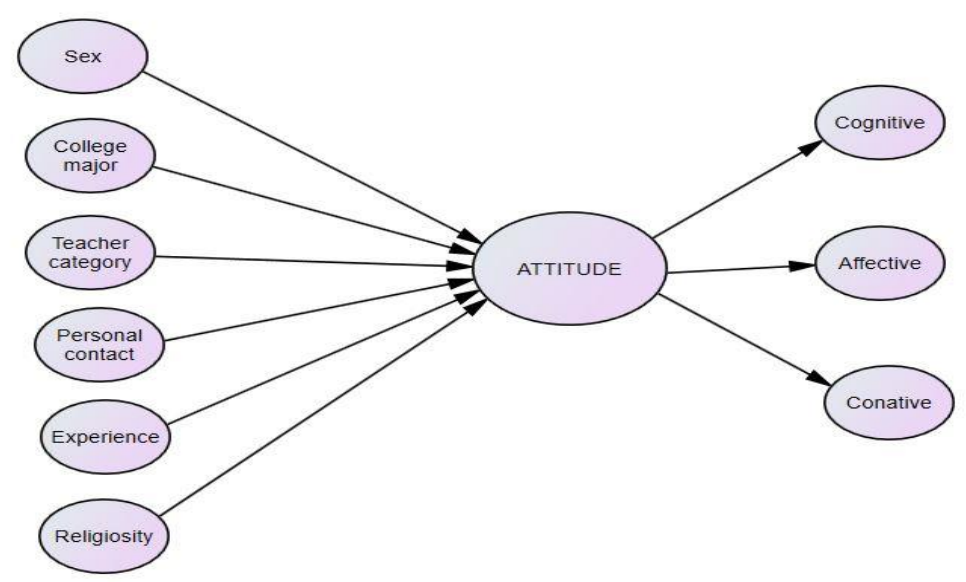

Image 1: The relationship between variables

\section{METHODS}

Based on the relationship between variables as discussed above (See image 1), data collection was carried out by distributing questionnaires online in South Kalimantan Province with convenience sampling techniques and obtained as many as 212 respondents. The respondents consisted of pre-service, beginner, and experienced teachers who worked in various public schools. Most pre-service teachers are students at teacher training and education colleges consisting of those who majored in general education and special education. Specifically, pre-service teachers are those who enroll in the teacher education program at the time of the survey, novice teachers are those who are experienced below the average teaching experience of sample member, and experienced teachers are those who are experienced above the average teaching experience (Huang \& Chen, 2017).

To assess attitudes toward inclusive education, respondents were asked to respond to several statements grouped into three attitude dimensions which include: 1) cognitive dimension consisting of 12 true or false statements aimed at measuring the level of knowledge of participants towards inclusive education. For example: "Facilities for students with 
disabilities are not needed in public schools"; "Inclusive schools only benefit students with disabilities"; "Inclusive classes need teachers who can communicate with a variety of methods" 2) The affective dimension has seven statements that must be assessed by respondents by choosing five available answer choices (5-point Likert scale) ranging from strongly agree (weight 5) to strongly disagree (weight 1) include: "I like to spend my time teaching students with disabilities"; "I want the school to accommodate students with disabilities"; "I am interested in learning sign language" 3) The conative dimension has eight statements that must be assessed on a 5-point Likert scale ranging from strongly agree (weight 5) to strongly disagree (weight 1), among others: "I am not willing to give extra time to students with disabilities "; "I am willing to ask schools not to reject students with disabilities": "I am willing to devote time and energy to learning sign language." Cronbach's alphas values for the seven items of affective statements and eight items of conative statements showed good internal consistency, respectively 0.82 and 0.81 .

Religiosity variables are placed in the third part of the questionnaire and are measured using a 5-point Likert scale ( $5=$ strongly agree and $1=$ strongly disagree) by submitting eight items of statements including: "I always pray five times a day"; "I really want to go on the pilgrimage to Mecca"; "I always pray to the mosque"; "I always join recitation"; "Women must wear the hijab"; "I can't shake hands with a woman who isn't my partner." Cronbach's alphas values for the eight items of statement of religiosity show good internal consistency $(\alpha=0.82)$. Furthermore, respondents are divided into two groups, those who have a religious score above the average sample value into the religious category while those who have a score below the average value fall into the category of less religious.

Analysis of research data was conducted using multivariate analysis of variance (Manova) with the help of IBM SPSS Statistics 26 to measure the influence of categorical independent variables on several dependent variables with a quantitative data scale. The independent variables in this study are gender, educational background (general and special), teaching experience (experienced and less experienced), categories of teachers (general and special teachers), personal contact (with or without contact) and religiosity (religious and less religious). While the dependent variable is the attitude in the dimensions of cognitive, affective and conative all of which have quantitative data.

\section{RESULTS}

As shown by table 1, this study has six independent variables, each of which has two levels: gender (female or male), college major (general or special), teacher category (general or special), personal contact (having previous personal experience with disabled person or without personal experience), teaching experience (experienced or less experienced), and religiosity (religious or less religious). The results of data collection succeeded in getting 212 respondents, from this number most of the respondents were women $(80.2 \%)$, most had general teacher education background $(62.3 \%)$, and most of them were experienced teachers $(61.3 \%)$ ie those with teaching experience above the average $(\mathrm{M}=12.3$ years, $\mathrm{SD}=10.0$ years $)$. Most respondents were special education teachers $(55.7 \%)$ and generally had personal contact with the disabled before becoming teachers $(70.8 \%)$. In terms of religiosity, the results of data 
processing showed that the majority of respondents had religiosity that could be categorized as strong (64.6\%) ie those who showed above-average religiosity scores $(\mathrm{M}=28.2, \mathrm{SD}=3.96)$.

Table 1: Independent categorical variables

\begin{tabular}{llcc}
\hline Variables & Categories & Frequency & Percent \\
\hline Sex & Female & 170 & 80.2 \\
& Male & 42 & 19.8 \\
College & General & 132 & 62.3 \\
major & Special & 80 & 37.7 \\
Teacher & General & 94 & 44.3 \\
category & Special & 118 & 55.7 \\
Personal & Yes & 150 & 70.8 \\
contact & No & 62 & 29.2 \\
Experience & Yes & 130 & 61.3 \\
& No & 82 & 38.7 \\
Religiosity & Religious & 137 & 64.6 \\
& Less religious & 75 & 35.4 \\
\hline
\end{tabular}

$\mathrm{N}=212$

Table 2: Correlation between dependent scale variables

\begin{tabular}{lcccc}
\hline & Cognitive & Affective & Conative & Mean \pm Standard Deviation \\
\cline { 2 - 5 } Cognitive & 1 & .126 & -.016 & $10.0 \pm 1.2$ \\
Affective & .126 & 1 & $.681^{* *}$ & $29.2 \pm 3.0$ \\
Conative & -.016 & $.681^{* *}$ & 1 & $33.5 \pm 3.0$ \\
\hline
\end{tabular}

**Correlation is significant at the 0.01 level (2-tailed)

Before performing a one-way multivariate analysis of variance, a Pearson correlation test was performed on all dependent variables of research (cognitive, affective and conative) to meet MANOVA's assumption that dependent variables have correlations with each other at a moderate level. The correlation results show a value between -.02 to .68 or an average correlation value of 0.30 which means meeting the ANOVA assumptions (See Table 2). Although the variance homogeneity assumption test result conducted on the three dependent variables concerning the six independent variables indicate an inadequate level of variance homogeneity (Box's test and Lavene's test <.05), except for the experience variable and the teacher category, which shows value>. 05, but according to Howell (2009), the MANOVA test can still be done if the dependent variable shows the largest standard deviation value that does not exceed four times the smallest value, and the three dependent variables used have fulfilled this provision (See table 2). In addition, the indicator of homogeneity only applies if the sample used has the same size (Tabachnick \& Fidell, 2007), while this study has a different sample size for each different group (unequal sample size).

Analysis results with Manova showed no significant differences in attitudes between male and female teachers simultaneously in all dimensions including cognitive, affective and conative, Wilks' $\lambda=.97, \mathrm{~F}(3,208)=13.02, \mathrm{p}=.096$, partial $\eta 2=.03$ (See Table 3 ). However, 
individual calculation with ANOVA for each dependent variable (attitude dimension) with an alpha level of .05 indicating only the affective dimension has a significant difference between male and female teachers, $F(1,210)=5.07, p<.05$, partial $\eta 2=.024$, with female teachers showing higher scores $(M=29.4)$ than male teachers $(M=28.3)$ (See Table 4). There were no significant differences between male and female teachers in the cognitive dimension $\mathrm{F}(1,210)$ $=.083, p=.77$, partial $\eta 2=.00$ and conative $F(1,210)=.46, p=.50$, partial $\eta 2=.002$

Concerning the college majors, there were significant differences in attitudes between special and general education students simultaneously in all dimensions including cognitive, affective and conative, Wilks' $\lambda=.842, \mathrm{~F}(3,208)=13.02, \mathrm{p}<0.01$, partial $\eta 2=.16$. A separate ANOVA calculation is performed for each dependent variable (dimension of attitude) with an alpha level of .05. Calculation results show there are significant differences between special and general education students in the cognitive dimension, $F(1,210)=8.42, p<.05$, partial $\eta 2$ $=.004$, with special education students showing higher scores $(\mathrm{M}=10.3)$ compared general education students $(M=9.8)$. There is a significant difference between special and general education students in the affective dimension, $F(1,210)=30.52, p<.001$, partial $\eta 2=.13$, with special education students showing higher scores $(\mathrm{M}=30.6)$ compared to general education students $(M=28.4)$. There is a significant difference between special and general education students in the conative dimension, $F(1,210)=5.71, p<.05$, partial $\eta 2=.03$, with special education students showing higher scores $(\mathrm{M}=34.1)$ compared to general education students $(\mathrm{M}=33.1)$.

In terms of teacher category, there are significant differences in attitudes between special teachers and general teachers simultaneously in all dimensions including cognitive, affective and conative, Wilks' $\lambda=.956, \mathrm{~F}(3,208)=3.18, \mathrm{p}<0.05$, partial $\eta 2=.04$. A separate ANOVA calculation was performed for each attitude dimension variable with an alpha level of .05. Calculation results show there are significant differences between special and general teachers in the affective dimension, $\mathrm{F}(1,210)=4.41, \mathrm{p}<.05$, partial $\eta 2=.021$, with special teachers showing higher scores $(M=29.6)$ compared to general teachers $(M=28.7)$. But no significant differences were found in the cognitive dimensions $F(1,210)=2.66, p=.11$, partial $\eta 2=.012$ and conative $\mathrm{F}(1,210)=.00, \mathrm{p}=.988$, partial $\eta 2=.00$

Table 3: Manova and Anova calculation results

\begin{tabular}{|c|c|c|c|c|c|c|}
\hline & \multicolumn{3}{|c|}{ Wilks' $\lambda$} & \multicolumn{2}{|c|}{ ANOVAs } & \multirow[b]{2}{*}{$\eta^{2}$} \\
\hline & Box's test & $F_{(3,208)}$ & $p$ & $F_{(1,210)}$ & $p$ & \\
\hline Sex & .027 & 2.14 & .096 & 13.02 & .096 & .03 \\
\hline College major & .000 & 13.02 & $* * *$ & 13.02 & $* * *$ & .16 \\
\hline Teacher category & .107 & 3.18 & $* *$ & 3.18 & $* *$ & .04 \\
\hline Personal contact & .003 & 5.37 & $* *$ & 5.37 & $* *$ & .072 \\
\hline Experience & .098 & .85 & .46 & .85 & .46 & .012 \\
\hline Religiusity & .000 & 11.82 & $* * *$ & 11.82 & $* * *$ & .15 \\
\hline
\end{tabular}

Table 4: Descriptive statistic of independent variables

ISSN 1869-0459 (print)/ ISSN 1869-2885 (online) 


\begin{tabular}{lccc}
\hline & $\begin{array}{c}\text { Cognitive } \\
(\overline{\boldsymbol{X}} \pm \text { SD })\end{array}$ & $\begin{array}{c}\text { Affective } \\
(\overline{\boldsymbol{X}} \pm \text { SD })\end{array}$ & $\begin{array}{c}\text { Conative } \\
(\overline{\boldsymbol{X}} \pm \text { SD })\end{array}$ \\
\cline { 2 - 4 } Male & $9.95 \pm 1.01$ & $28.29 \pm 3.14$ & $33.19 \pm 2.57$ \\
Female & $10.01 \pm 1.24$ & $29.42 \pm 2.89$ & $33.54 \pm 3.12$ \\
Special education & $10.30 \pm 1.26$ & $30.55 \pm 2.60$ & $34.10 \pm 2.94$ \\
General education & $9.82 \pm 1.26$ & $28.38 \pm 2.87$ & $33.10 \pm 3.00$ \\
Special teacher & $10.12 \pm 1.14$ & $29.57 \pm 2.83$ & $33.47 \pm 3.24$ \\
General teacher & $33.47 \pm 2.72$ & $28.72 \pm 3.07$ & $33.47 \pm 2.72$ \\
With personal contact & $10.12 \pm 1.11$ & $29.64 \pm 2.73$ & $33.65 \pm 2.90$ \\
No personal contact & $9.74 \pm 1.33$ & $28.13 \pm 3.25$ & $33.03 \pm 3.26$ \\
Experienced & $10.05 \pm 1.16$ & $29.34 \pm 2.89$ & $33.41 \pm 3.21$ \\
Less experienced & $9.93 \pm 1.25$ & $28.98 \pm 3.07$ & $33.60 \pm 2.69$ \\
Religious & $9.85 \pm 1.23$ & $29.43 \pm 3.30$ & $34.18 \pm 3.16$ \\
Less religious & $10.28 \pm 0.97$ & $28.77 \pm 2.17$ & $32.17 \pm 2.23$ \\
\hline
\end{tabular}

There are significant differences in attitudes between those who have personal contact with disabled persons before entering the teaching profession and those who do not have personal contact simultaneously in all dimensions including cognitive, affective and conative, Wilks' $\lambda=.928, \mathrm{~F}(3,208)=5.37, \mathrm{p}<0.05$, partial $\eta 2=.072$. A separate ANOVA calculation is performed for each dimension of attitude with an alpha level of .05. Calculation results show that there are significant differences between teachers who have previous personal contacts and teachers without personal contacts in the cognitive dimension, $\mathrm{F}(1,210)=4.17, \mathrm{p}<.05$, partial $\eta 2=.02$, teachers with contacts show higher scores $(\mathrm{M}=10.1)$ compared to teachers without contacts $(M=9.7)$. There is a significant difference between teachers with contacts and without contacts in the affective dimension, $\mathrm{F}(1,210)=12.02, \mathrm{p}<.005$, partial $\eta 2=.054$, teachers with contacts show higher scores $(M=29.6)$ than without contacts $(M=28.1)$. There was no significant difference between teachers with contacts and without contacts in the conative dimension, $F(1,210)=1.87, p=.17$, partial $\eta 2=.009$.

There is no significant difference in attitude between experienced teachers and lessexperienced teachers simultaneously in all dimensions including cognitive, affective and conative, Wilks' $\lambda=.99, \mathrm{~F}(3,208)=.85, \mathrm{p}=.46$, partial $\eta 2=.012$. Separate ANOVA calculations performed for each dimension of attitude with an alpha level of .05 also showed no significant difference between experienced teachers and less-experienced in all three dimensions of attitude: cognitive, $\mathrm{F}(1,210)=.50, \mathrm{p}=.48$, partial $\eta 2=.002$; affective, $\mathrm{F}(1$, $210)=.754, p=.386$, partial $\eta 2=.004$ and; conative, $F(1,210)=.117, p=.73$, partial $\eta 2=$ .001 .

In terms of religiosity, there are significant differences in attitudes between religious and less-religious teachers simultaneously in all dimensions including cognitive, affective and conative, Wilks' $\lambda=.854, \mathrm{~F}(3,208)=11.82, \mathrm{p}<0.01$, partial $\eta 2=.15$. A separate ANOVA calculation was performed for each dimension of attitude with an alpha level of .05 . The 
calculation results show there are significant differences between religious and less-religious teachers in cognitive and conative dimensions. In the cognitive dimension, $\mathrm{F}(1,210)=6.57$, $\mathrm{p}<.05$, partial $\eta 2=.03$, less-religious teachers show higher cognitive scores $(\mathrm{M}=10.3)$ than religious ones $(M=9.8)$. While in the conative dimension, $F(1,210)=23.87, p<.01$, partial $\eta 2=.102$, religious teachers showed higher scores $(\mathrm{M}=34.2)$ compared to less-religious teachers $(M=32.2)$. In the affective dimension, data analysis did not show any significant difference between religious and less-religious teachers, $F(1,210)=2.41, p=.12$, partial $\eta 2$ $=.01$.

\section{DISCUSSION AND CONCLUSIONS}

The results of the survey toward teachers and students majoring in education in South Kalimantan provide clarity on several issues regarding teacher attitudes toward inclusive education. Broadly speaking, teachers in South Kalimantan could accept the application of inclusive education to provide wider learning opportunities for students with disabilities. Also, teachers often feel sorry and reasonable if they help following what they can do. The desire to provide this assistance is often driven by religious and cultural factors. Only a small proportion of teachers have not been able to receive inclusive education to be applied in public schools for the main reason they do not have teaching competence for students with disabilities. Also, they have difficulty managing classes that have very diverse abilities and characteristics.

The present findings also confirm the results obtained from previous studies. Significant differences were found between male and female teachers, special and general education students, special and general teachers, teachers with or without personal contacts, religious and less religious teachers. However, this does not mean that differences occur in all three dimensions of attitude. Some differences only occur in one or two dimensions, but some occur in all three dimensions. The more dimensions involved significantly are of course an indication of a very strong attitude towards inclusive education. Educational background (special and general) and personal contact are the two independent variables that show the most different attitudes towards inclusive education. Both simultaneously or individually, the two independent variables show significant differences in the three attitude dimensions.

The teacher categories, special and general, only show significant differences if the two independent sub-variables work together but individually only the affective dimension shows significant differences. Similar to the teacher's category, religiosity also shows a significant difference if the two sub-variables of religiosity work together but individually only the affective dimension shows a significant difference between religious and non-religious teachers. Finally, gender differences differ only in the affective dimension. Thus if arranged according to the strengths of each variable in influencing attitudes can be arranged to start from the strongest to the weakest are educational background and personal contact as the most influential or strongest variable. Furthermore, the teacher category, teacher religiosity, and gender show moderate (moderate) influence, while experience did not show significant influence.

Some findings are in line with previous studies. For example, the findings of this study show that there are differences between special and general education students on the overall attitude dimensions where special education students show greater support for inclusive 
education. This result is in line with the findings of Ahsan et al (2012) who found that the type of teacher education preparation program is a strong predictor for adopting inclusive education. Similarly, the findings by Huang and Chen (2017) conclude that pre-service teachers who enroll in special education pathways are more comfortable teaching students with disabilities than their peers who enroll in general education pathways (Huang \& Chen, 2017).

Likewise, the results of this study which show that teachers with personal contacts show better attitudes towards inclusive education compared to teachers without personal contacts have similarities with the findings of Ahsan et al (2012) which states that age and previous experience with people with disabilities are strong predictors of teacher willingness to implement inclusive education. In addition, older teachers are less worried about teaching students with special needs.

In the case of special and general teachers, the results of this study indicate that there are significant differences in the attitudes of special and general teachers in the overall attitude dimensions, especially the affective dimension. This result is in line with the findings of Alghazo and Gaad (2004) which states that there are significant differences in teacher attitudes that are influenced by experience in teaching. Similarly, the findings of Avramidis and Kalyva (2007) which show that teachers who are actively involved in learning how to teach students with disabilities have a much more positive attitude towards inclusive education than their peers without such training.

In terms of the role of religion, this study shows that the religion of Islam embraced by the majority of teachers in South Kalimantan has a significant role in encouraging teachers' acceptance of inclusive education. This is in line with the findings of Naemiratch and Manderson (2009) and Kantavong (2017) in Thailand which shows that the religion of the people in that country provides a philosophical basis for the application of inclusive education. They found that people showed their generosity and helped students with disabilities with the belief that they were building good karma to avoid misfortune in their later lives.

The limitation of this study is the fulfillment of statistical assumptions that are not yet fully satisfactory. For example, correlations between dependent variables should have a moderate correlation with each other (Tabachnick \& Fidell, 2007). In this study, not all dependent variables show a moderate level as desired. Similarly, the level of homogeneity of variants is inadequate on several independent variables. However, statistical analysis can still be done based on the argument that the sample sizes in each group of variables are not the same (Howell, 2009).

The study's main contribution is providing a fairly complete explanation of the thinking and readiness of teachers in South Kalimantan for the implementation of inclusive education in the area. The results show that, in South Kalimantan, inclusive education policies are still viewed differently among teachers due to different individual backgrounds. However, most teachers can accept the presence of inclusive education in their schools. This research makes an important contribution because studies on the readiness and attitudes of inclusive education teachers are still very rare. It is also worth noting that most teachers accept the basic idea that children with disabilities can be accepted in public classrooms and receive lessons like other normal children. These results confirm that there is potential for the successful implementation of inclusive education in South Kalimantan. 


\section{REFERENCES}

[1]. Abbott, L. (2006). Northern Ireland head teachers' perceptions of inclusion. International Journal of Inclusive Education, 10(6), 627-643. https://doi.org/10.1080/13603110500274379

[2]. Ahsan, M. T., Deppeler, J. M., \& Sharma, U. (2013). Predicting pre-service teachers' preparedness for inclusive education: Bangladeshi pre-service teachers' attitudes and perceived teaching-efficacy for inclusive education. Cambridge Journal of Education, 43(4), 517-535. https://doi.org/10.1080/0305764X.2013.834036

[3]. Al-Zyoudi, M. (2006). Teachers' attitudes towards inclusive education in Jordanian schools. Inernational Journal of Special Education, $21(2), \quad 55-62$. https://www.researchgate.net/publication/289651204_Teachers\%27_attitudes_towards_inclusive_educ ation_in_Jordanian_schools

[4]. Alghazo, E. M., \& Naggar Gaad, E. El. (2004). General education teachers in the united arab emirates and their acceptance of the inclusion of students with disabilities. British Journal of Special Education, 31(2), 94-99. https://doi.org/10.1111/j.0952-3383.2004.00335.x

[5]. Avramidis, E., Bayliss, P., \& Burden, R. (2000). A survey into mainstream teachers' attitudes towards the inclusion of children with special educational needs in the ordinary school in one local education authority. Educational Psychology, 20(2), 191-211. https://doi.org/10.1080/713663717

[6]. Avramidis, E., \& Kalyva, E. (2007). The influence of teaching experience and professional development on Greek teachers' attitudes towards inclusion. European Journal of Special Needs Education, 22(4), 367-389. https://doi.org/10.1080/08856250701649989

[7]. Avramidis, E., \& Norwich, B. (2002). Teachers' attitudes towards integration/inclusion: A review of the literature. In European Journal of Special Needs Education (Vol. 17, Issue 2, pp. 129-147). Taylor \& Francis Group . https://doi.org/10.1080/08856250210129056

[8]. Buell, M. J., Hallam, R., Gamel-Mccormick, M., \& Scheer, S. (1999). A survey of general and special education teachers' perceptions and inservice needs concerning inclusion. International Journal of Disability, Development and Education, 46(2), 143-156. https://doi.org/10.1080/103491299100597

[9]. de Boer, A., Pijl, S. J., \& Minnaert, A. (2011). Regular primary schoolteachers' attitudes towards inclusive education: a review of the literature. International Journal of Inclusive Education, 15(3), 331353. https://doi.org/10.1080/13603110903030089

[10]. Derbaix, C., \& Pham, M. T. (1991). Affective reactions to consumption situations: A pilot investigation. Journal of Economic Psychology, 12(2), 325-355. https://doi.org/10.1016/0167-4870(91)90019-P

[11]. Diduca, D., \& Joseph, S. (1997). Schizotypal traits and dimensions of religiosity. British Journal of Clinical Psychology, 36(4), 635-638. https://doi.org/10.1111/j.2044-8260.1997.tb01270.x

[12]. Eagly, A. H., \& Chaiken, S. (1993). The psychology of attitudes. New York: Harcourt, Brace, \& Janovich. New York: Harcourt, Brace, \& Janovich. https://www.researchgate.net/publication/258879638_A_review_Eagly_A_H_Chaiken_S_1993_The_p sychology_of_attitudes_New_York_Harcourt_Brace_Janovich

[13]. Effendi, M. . (2018, June 17). 2 Ribu Anak Difabel di Kalsel Butuh Sekolah Inklusif. Kumparan.Com.

[14]. Fishbein, M., \& Ajzen, I. (1975). Belief, Attitude, Intention and Behaviour An Introduction to Theory and Research. Addison-Wesley Publishing Co, Inc., Boston. https://www.scirp.org/(S(351jmbntvnsjt1aadkposzje))/reference/ReferencesPapers.aspx?ReferenceID= 1124363

[15]. Florian, L. (2008). Special or inclusive education: Future trends. British Journal of Special Education, 35(4), 202. https://doi.org/10.1111/j.1467-8578.2008.00402.x

[16]. Gall, M. ., Borg, W. ., \& Gall, J. . (2003). Educational Research: An Introduction. Pearson. https://www.pearson.com/us/higher-education/product/Gall-Educational-Research-An-Introduction7th-Edition/9780321081896.html

[17]. Glock, C. Y. (1962). On the study of religious commitment. Religious Education, 57, 98-110. https://doi.org/10.1080/003440862057S407

[18]. Hart, H. (1945). Sociology of Religion. By Joachim Wach. Chicago: University of Chicago Press, 1944. 412 pp. \$5.00. Social Forces, 23(4), 476-477. https://doi.org/10.2307/2571856

[19]. Havitz, M. E., \& Dimanche, F. (1997). Leisure involvement revisited: Conceptual conundrums and 
measurement advances. Journal of Leisure Research, 29(3), 245-278. https://doi.org/10.1080/00222216.1997.11949796

[20]. Hifni, A. (2018). Perbedaan dalam Pandangan Islam. https://www.aida.or.id/2018/10/3138/damaidalam-perbedaan

[21]. Horley, J., \& Little, B. . (1985). Affective and cognitive component of global subjective well-being measures. Social Indicator Research, 24, 189-197.

[22]. Howell, D. C. (2009). Statistical Methods for Psychology. Chp. 12: Multiple comparisons. 1-91.

[23]. Huang, C.-H., \& Chen, R. (2017). (PDF) Attitudes toward Inclusive Education: A Comparison of General and Special Education Teachers in Taiwan. Asian Journal of Inclusive Education, 5(1), 23-37. https://www.researchgate.net/publication/319872793_Attitudes_toward_Inclusive_Education_A_Com parison_of_General_and_Special_Education_Teachers_in_Taiwan

[24]. Huber, S., \& Huber, O. W. (2012). The Centrality of Religiosity Scale (CRS). Religions, 3(3), $710-724$. https://doi.org/10.3390/rel3030710

[25]. Khadafi, A. (2017). Ketika Nabi Muhammad Ditegur Tuhan - Tirto.ID. https://tirto.id/ketika-nabimuhammad-ditegur-tuhan-cpGL

[26]. MacKenzie, S. B., \& Lutz, R. J. (1989). An Empirical Examination of the Structural Antecedents of Attitude toward the Ad in an Advertising Pretesting Context. Journal of Marketing, 53(2), 48. https://doi.org/10.2307/1251413

[27]. Marshall, J., Ralph, S., \& Palmer, S. (2002). “I wasn't trained to work with them”: Mainstream teachers' attitudes to children with speech and language difficulties. International Journal of Inclusive Education, 6(3), 199-215. https://doi.org/10.1080/13603110110067208

[28]. McIntyre, E. (1992). Young Children's Reading Behaviors in Various Classroom Contexts. Journal of Reading Behavior, 24(3), 339-371. https://doi.org/10.1080/10862969209547781

[29]. Naemiratch, B., \& Manderson, L. (2009). Pity and pragmatism: Understandings of disability in northeast Thailand. Disability and Society, 24(4), 475-488. https://doi.org/10.1080/09687590902879106

[30]. Nasichin. (2001). Kebijakan Direktorat Pendidikan Luar Biasa.Jurnal Rehabilitasi Dan Remedial. Jurnal Rehabilitasi Dan Remedial, 11(2).

[31]. Pearce, E., Launay, J., Machin, A., \& Dunbar, R. I. M. (2016). Is Group Singing Special? Health, WellBeing and Social Bonds in Community-Based Adult Education Classes. Journal of Community and Applied Social Psychology, 26(6), 518-533. https://doi.org/10.1002/casp.2278

[32]. Pearman, E. L., Huang, A. M., \& Mellblom, C. I. (1997). The Inclusion of All Students: Concerns and Incentives of Educators. In Education and Training in Mental Retardation and Developmental Disabilities (Vol. 32, pp. 11-20). Division on Autism and Developmental Disabilities. https://doi.org/10.2307/24481561

[33]. Pearson, V., Lo, E., Chui, E., \& Wong, D. (2003). A heart to learn and care? Teachers' responses toward special needs children in mainstream schools in Hong Kong. In Disability and Society (Vol. 18, Issue 4, pp. 489-508). Taylor \& Francis Group . https://doi.org/10.1080/0968759032000081020

[34]. Ring, E., \& Travers, J. (2005). Barriers to inclusion: A case study of a pupil with severe learning difficulties in Ireland. European Journal of Special Needs Education, 20(1), 41-56. https://doi.org/10.1080/0885625042000319070

[35]. Saloviita, T. (2020). Attitudes of Teachers Towards Inclusive Education in Finland. Scandinavian Journal of Educational Research, 64(2), 270-282. https://doi.org/10.1080/00313831.2018.1541819

[36]. Schiffman, L. ., \& Kanuk, L. L. (2004). Consumer Behavior. Amazon.com. https://www.amazon.com/Consumer-Behavior-8th-Leon-Schiffman/dp/B009TUK8HW

[37]. Scott, L. P., Jellison, J. A., Chappell, E. W., \& Standridge, A. A. (2007). Talking with music teachers about inclusion: perceptions, opinions and experiences. Journal of Music Therapy, 44(1), 38-56. https://doi.org/10.1093/jmt/44.1.38

[38]. Subekti, I. (2017). Pendidikan inklusif dalam pandangan Islam: Studi kasus di SMK Negeri 8 Surakarta tahun pelajaran 2016/2017 [Universitas Muhammadiyah Surakarta]. http://eprints.ums.ac.id/52385/1/NASKAH PUBLIKASI ILMIAH.pdf

[39]. Sunardi. (2010). Kurikulum Pendidikan Luar Biasa di Indonesia Dari Masa Ke Masa. https://www.researchgate.net/publication/337220616_Sikap_Orang_Tua_Terhadap_Pendidikan_Inklus 
if

[40]. Supriyanto, D. (2019). Teachers' Attitudes Towards Inclusive Education: A Literature Review. IJDS:INDONESIAN JOURNAL OF DISABILITY STUDIES, 6(1), 29-37.

[41]. Tabachnick, B. G., \& Fidell, L. S. (2007). Using Multivariat Statistics. Pearson Education, Inc. / Allyn and Bacon. https://www.researchgate.net/publication/270761711_Using_Multivariat_Statistics

[42]. Triandis, H. C. (1971). Attitude and Attitude Change (Foundations of Social Psychology). Hoboken, NJ John Wileys \& Sons Inc. - References - Scientific Research Publishing. https://www.scirp.org/(S(351jmbntvnsjt1aadkposzje))/reference/ReferencesPapers.aspx?ReferenceID= 2516600

[43]. Vorapanya, S., \& Dunlap, D. (2014). Inclusive education in Thailand: Practices and challenges. International Journal of Inclusive Education, 18(10), 1014-1028. https://doi.org/10.1080/13603116.2012.693400

[44]. Wathoni, K. (2013). Implementasi Pendidikan Inklusi dalam Pendidikan Islam. Ta'allum: Jurnal Pendidikan Islam, 1(1), 99-109. https://doi.org/10.21274/taalum.2013.1.1.99-109 